\title{
Journal of Bentham Studies
}

\section{An Introduction to Jeremy Bentham's Theory of Punishment}

\section{Tony Draper ${ }^{1}$}

How to cite: Draper, T. 'An Introduction to Jeremy Bentham's Theory of Punishment.' Journal of Bentham Studies, 2002, 5(1): 1, pp. 1-17. DOI: https://doi.org/10.14324/111.2045-757X.018.

Published: 01 January 2002

\section{Peer Review:}

This article has been peer reviewed through the journal's standard double blind peer review.

\section{Copyright:}

(C) 2002, The Author(s). This is an Open Access article distributed under the terms of the Creative Commons Attribution-Non Commercial- No Derivatives 2.0 International License (CC BY-NC-ND 2.0) https://creativecommons.org/licenses/by-nc-nd/2.0/, which permits re-use, distribution and reproduction in any medium, provided the original material is not modified, is not used for commercial purposes, and the original author and source are credited • DOI: https://doi.org/10.14324/111.2045-757X.018

\section{Open Access:}

Journal of Bentham Studies is a peer-reviewed open access journal. 


\title{
An Introduction to Jeremy Bentham's Theory of
}

\section{Punishment}

\author{
TONY DRAPER
}

Bentham Project, University College London

\section{Introduction}

Bentham's penal theory has yet to be fully examined. ${ }^{1}$ Indeed, conventional commentary has tended to focus on the architectural device of the panopticon penitentiary rather than on any detailed assessment of the principles of punishment on which the prison was based. ${ }^{2}$ Some critics have gone so far as to draw Bentham's general penal principles from the regime proposed for the panopticon. ${ }^{3}$ In the process such commentators have tended to ignore Bentham's own penal ideas in favour of one of his penal devices; and, whilst his devices are of value, none of them ought to be allowed to overshadow the ideas on which they were founded. ${ }^{4}$ The net result of the controversy surrounding the panopticon prison is that ideas of surveillance, control and regimentation, are now immediately, and often erroneously, brought to mind with

\footnotetext{
${ }^{1}$ Most discussions rely upon the general surveys of E. Halévy, La formation du radicalisme philosophique, 3 vols., Paris, 1901-4, hereafter references are to the translation by M. Morris, The Growth of Philosophic Radicalism, London, 1928; rept. 1972; and L. Radzinowicz, A History of English Criminal Law, 4 vols., London, 1948-86, hereafter references are to vol. i. Recently, more detailed work has been done by H.L.A. Hart, 'Bentham and Beccaria', Essays on Bentham: Studies in Jurisprudence and Political Theory, Oxford, 1982; and F. Rosen, 'New Introduction', in An Introduction to the Principles of Morals and Legislation, Oxford, 1996 (The Collected Works of Jeremy Bentham, henceforth IPML $(C W)$, pp. xxxi-lxxviii. On Bentham and the death penalty see H.A. Bedau, 'Bentham's Utilitarian Critique of the Death Penalty', The Journal of Criminal Law, lxxiv. (1985), pp. 1033-65; and J.E. Crimmins, 'Strictures on Paley's Net: Capital Punishment and the Power to Pardon', Bentham Newsletter, xi. (1987), pp. 23-34.

${ }^{2}$ Since the publication of Michel Foucault's Surveiller et punir: Naissance de la prison, Paris, 1975, trans. Alan Sheridan, Discipline and Punish: The Birth of the Prison, London, 1977, Bentham's panopticon has frequently been taken as evidence of a more coercive and regimented society. See also M. Ignatieff, A Just Measure of Pain: The Penitentiary in the Industrial Revolution, 1750-1850, New York, 1978, pp. 77-8. For a criticism of Foucault's position see J. Semple, 'Foucault and Bentham: A Defence of Panopticism', Utilitas, iv. (1992), pp. 105-20.

${ }^{3}$ See Foucault, Discipline and Punish; G. Himmelfarb, 'The Haunted House of Jeremy Bentham', Victorian Minds, London, 1968; C.F. Bahmueller, The National Charity Company: Jeremy Bentham's Silent Revolution, California, 1981; and D.J. Manning, The Mind of Jeremy Bentham, London, 1968. Such commentaries appear to exaggerate the relevance of the idea of the panopticon institution to give weight, it seems, to their own schemes. Professor Roy Porter has convincingly shown how disciplinary institutions were not, in the eighteenth century, used by the British state for the purposes suggested by Foucault, i.e. as a means of regimentation and incarceration. See R. Porter, Mind Forg'd Manacles: A History of Madness in England from the Restoration to the Regency, London, 1987, pp. 141 and 168.
} 
the mention of Bentham and punishment. ${ }^{5}$ It is important to stress, therefore, that before embarking upon any consideration of Bentham's penal theory, it is necessary first to dissociate the pervasive and pejorative ideas surrounding the panopticon prison from the underlying penal theory upon which the scheme for imprisonment was based. Surveillance, control, and regimentation are not the inevitable products of Bentham's thinking on punishment, and the panopticon project, which emphasised such concepts so implacably, must be seen simply as one amongst many suggested forms of complex punishment. ${ }^{6}$

It can be argued that Bentham's penal writings provide a substantial, comprehensive and sophisticated justification for the infliction of legal punishment. In this regard they form a central part of the construct described by Gerald Postema as, 'a jurisprudential debate of historic dimensions and fundamental philosophical significance'. ${ }^{7}$ Individual human motivation is given prominence throughout the process of re-affirming the value of legal systems as a means of ensuring fair treatment and security for the entire citizen body. In displaying the complexities and subtleties required in the recognition of individual circumstances and sensibilities, Bentham emphasised the primary role of legislation as a defender of the security and welfare of the individual. The premise from which Bentham started was that no two people are the same, no two crimes are the same, and it is the duty of the law to accommodate such variables before inflicting pain, in the name of the state, for the protection of itself and other citizen members of that state. As Sir Leon Radzinowicz put it,

\footnotetext{
${ }^{4}$ For two notable exceptions which do take account of Bentham's penal thinking see J. Semple, Bentham's Prison: A Study of the Panopticon Penitentiary, Oxford, 1993 and S. McConville, A History of English Prison Administration, London, 1981.

${ }^{5}$ As Garland has shown, this is predominantly due to the influence of Foucault, "whose... inflated rhetoric takes over and describes modern society as "the disciplinary society" - a "society of surveillance" in which we are all subjected to "infinite examination" in the "panoptic machine". D. Garland, Punishment and Modern Society: A Study in Social Theory, Oxford, 1990, p. 146. Garland confronts the greatest excesses of Foucault in 'Beyond the Power Perspective: A Critique of Foucault on Punishment', ibid., ch. 7.

${ }^{6}$ Indeed, Garland stresses that the penal theory contained within Bentham's IPML $(C W)$ is a vision of an ideal system of punishment, and is not, as Foucault imagines it to be, an actual description of eighteenth century punishment. Garland, Punishment and Modern Society, p. 163. Even a brief examination of Bentham's penal writings indicates how other forms of punishment, apart from imprisonment, could satisfy the demands of his theory.

${ }^{7}$ G.J. Postema, Bentham and the Common Law Tradition, Oxford, 1986, p. vii. A penal code was envisaged as one of the four main codes making up Bentham's Pannomion, the complete code of laws. See Constitutional Code, i. eds. F. Rosen and J.H. Burns (Oxford, 1983), (CW), p. xi.
} 
thus the subjective approach to criminal acts led Bentham to an equally subjective approach to punishment. He urged the adoption of a principle which in modern French criminal science has been called le principe de l'individualisation de la peine. ${ }^{8}$

This essay aims to introduce the key elements both of the historical context from within which such a penal theory was developed and of the theory itself, along with some mention also of the forms of punishment recommended. First, however, a few points ought to be made concerning the texts where Bentham's penal theory is to be found.

\section{Bentham's Punishment Writings}

Bentham's ideas on punishment are contained first, within his own published works, ${ }^{9}$ second, in a large body of extant manuscripts, and third, they are summarised in various versions produced by later editors. Reliance should be placed first and foremost upon work seen through the press by Bentham himself, though this is closely followed by manuscript material, which can provide hitherto unknown insights into Bentham's developed thinking on the subject. As far as the 'theory of punishment' is concerned by far the most important of the printed works is An Introduction to the Principles of Morals and Legislation and substantial and profitable use can, indeed should, be made of this well-known work if his theory is to be properly understood. All of the key elements discussed below can be found examined in this work. ${ }^{10}$

Despite the value of IPML, however, many valuable insights into the development of Bentham's theory have come directly from an exploration of his manuscripts and there is undoubtedly much more work to be done in the archive. Many hundreds of pages of text exist covering every aspect of penal theory from

\footnotetext{
${ }^{8}$ Radzinowicz, English Criminal Law, 376. Radzinowicz shows how this principle, established in R. Saleilles's book L'individualisation de la peine, Paris, 1898, had been discussed earlier in Austria by W.E. Wahlberg in the essay Das Princip der Individualisierung in der Strafrechtspflege, Vienna, 1869, rendered in English as 'The Necessity of Individualising'. See Radzinowicz., English Criminal Law, p. $14 n$.

${ }^{9}$ Apart from IPML two further works, published by Bentham himself, are particularly useful: A View of the Hard-Labour Bill, London, 1778, and Jer. Bentham to his fellow citizens of France on death punishment, London, 1831. Both are reproduced in, The Works of Jeremy Bentham, ed. J. Bowring, 11 vols. (Edinburgh, 1843); see iv. pp. 6-35 and i. pp. 525-32 respectively. Hereafter, 'Bowring'.

${ }^{10} I P M L$ was largely complete by 1780 , incorporating his penal theory developed during $1776-8$, but not published until 1789, when it appears to have attracted little attention. On its poor reception see $A n$
} 
initial principles to two attempts at the drafting of complete penal codes. ${ }^{11}$ The difficulties presented by the manuscripts are numerous. They are in a jumbled and confused state; there is much re-working of similar themes and topics; sometimes texts have been so heavily amended that neither the original nor the revised meanings are clear. Add to this the standard problem of uncertain dating for early Bentham manuscripts, and deteriorating script for later manuscripts, and the problems faced in the reconstruction of Bentham's intended penal thought are great. Nevertheless, the existence of manuscript material allows progress to be made in the recovery of Bentham's ideas, and despite the complexity and apparent confusion of the material it is certainly possible to claim that a coherent picture of Bentham's fundamental concerns and specific proposals in relation to punishment does emerge.

Once Bentham's discussion of punishment has been examined in IPML it is considerably safer to approach the published works compiled by his editors. In relation to punishment these include two works edited by Étienne Dumont, ${ }^{12}$ a recension by Richard Smith; ${ }^{13}$ and a production by John Bowring entitled, 'Principles of Penal Law'. ${ }^{14}$ These edited texts are frequently thought to offer the most convenient access to Bentham's discussions of punishment. They must, however, be treated with great care, mainly because it is difficult to identify exactly how far Bentham's text has been emended. The foundation for the vast majority of this editorial work is volume one of Dumont's Théorie des peines et des récompenses, and there are problems with Dumont's text. For not only did Dumont publish selectively from Bentham's manuscripts, but those manuscripts titled 'Theory of Punishment' were originally written in English. Thus, this key work, clearly containing an important treatment of Bentham's penal theory, was selectively translated and published in French in 1811, then retranslated back into English some nineteen years

Introduction to the Principles of Morals and Legislation $(C W)$, ed. J.H. Burns (London, 1970) p. xli, note 3 .

${ }^{11}$ Over 1500 folios are catalogued as containing material on penal theory. Several thousand more are related to his Penal Codes. See A. Taylor Milne, The Catalogue of the Manuscripts of Jeremy Bentham in the Library of University College, London, London, 1962. Bentham had great plans for his 'Punishments', hoping they would successively be published in England, translated into French, and perhaps even used in Poland. See Correspondence $(C W)$, ii. (1752-80), ed. T.L.S. Sprigge, London, 1968, letter 198, to his brother Samuel (19 January 1777), p. 11.

${ }^{12}$ É. Dumont, ed., Traités de législation civile et pénale, ed. É. Dumont, 3 vols., Paris, 1802, and Théorie des peines et des récompenses, 2 vols., London, 1811.

${ }^{13}$ R. Smith, ed., The Rationale of Punishment, London, 1830.

${ }^{14}$ Bowring, i. pp. 336-580. 
later in 1830, again with further changes being made; and finally, the work was incorporated into Bowring's edition in $1838 .^{15}$

Whilst the value of Dumont as an editor can be appreciated, so too must be his limitations. ${ }^{16}$ There can be little doubt that much important material has been omitted from Théorie des peines et récompenses, and even with recourse to the manuscripts it seems unlikely that some of the gaps left by Dumont will ever be effectively filled. ${ }^{17}$ Not only has much been omitted, however, but text has also been added, and again the source of many additions is likely to remain uncertain. Most additions probably came from the hand of Dumont, since, by his own admission, he treated the manuscripts very freely, ${ }^{18}$ yet, as was the rule for many editorial endeavours in the early nineteenth-century, such additions are rarely identified. Many previous commentators have carefully considered the problems presented by Dumont's renditions of Bentham's work and, despite the difficulties, most have concluded that his texts ought to be accepted as representative of Bentham's thought, even though they should be avoided wherever Bentham's own texts treat of the same material. ${ }^{19}$ It must therefore be stressed that the starting point for any study of Bentham's theory of punishment remains An Introduction to the Principles of Morals and Legislation.

\section{Historical Context}

By returning to the intellectual environment within which Bentham's penal theory was developed it can be seen that, whilst initially drawing from contemporary penal debate, his own analysis struck out in a radical new direction. From the starting point of Beccaria's On Crimes and Punishments ${ }^{20}$, Bentham pursued an explanation for

\footnotetext{
${ }^{15}$ See J.H. Burns's discussion on the dating of Bentham's 'Punishment' manuscripts on which Dumont based his edition, IPML $(C W)$, pp. xxxviii-xli.

${ }^{16}$ For a discussion of this see Lieberman, Province of Legislation, 288-90; R. Harrison, Bentham, London, 1983, pp. ix-xiv, 138-40; and, C. Blamires, 'Étienne Dumont: Genevan Apostle of Utility', Utilitas, ii. (1990), pp. 55-70.

${ }^{17}$ Many omissions were no doubt necessary since Dumont was seeking to produce a volume that would be readily understood. A further question concerns whether manuscripts can actually be found to compare Dumont's work with. See ibid.

18 'These manuscripts, though much more voluminous than the work I have presented to the public, are very incomplete [...] I have freely used the rights of an Editor - according to the nature of the text and the occasion, I have translated, commented, abridged, or supplied, but [...] this co-operation on my part has had reference to the details only, [...] it is not my work [...] it is, as faithfully as the nature of things will permit, the work of Mr. Bentham'. See É. Dumont's 'Advertisement', translated in Smith's, Rationale of Punishment, pp. 4-5.

${ }^{19}$ R. Harrison, Bentham, p. xii.

${ }^{20}$ Cesare Beccaria Bonesara, Dei delitti e delle pene, Leghorn, false imprint Haarlem, 1764,. First English edition: An Essay on Crimes and Punishments, translated from the Italian; with a commentary, attributed to Mons. de Voltaire, translated from the French, London, 1767.
} 
punishment which contrasted sharply with the notion of the 'vengeance of the state' on which many governments in Europe relied. ${ }^{21}$ In dramatically redirecting the search for a clarified justification of legal punishment, Beccaria's appealing mixture of Helvétian proto-utilitarian thought and Rousseauean contractarianism inceptively stated the need for penal theory to pursue more directly the welfare of all those in society. ${ }^{22}$

To these ends Beccaria advocated the protection of the liberties of those who adhered to the law; he emphasised the need to establish certainty and celerity of punishment for those who transgressed the law; and he sought to revive respect for the law by advocating a new mildness in the apportioning of punishment for those who broke the law. ${ }^{23}$ These humane and liberal principles were rapidly adopted by reformminded men and women across Europe ${ }^{24}$ and in England also, they were received with enthusiasm and admiration, although it has been argued that many men of status and wealth regarded Beccaria's criticisms as more appropriate to continental penal systems than to Britain's. ${ }^{25}$ For Bentham, Beccaria's work was exceptionally influential, and he used the penal principles reflected in On Crimes and Punishment to connect his own justifications for legal punishment firmly to a utilitarian base. And, although influenced by the powerful, ever-present influence of Montesquieu, Bentham's use of the catalytic thinking of Beccaria, combined with his own rejection of the traditional concepts of common law and social contract, ${ }^{26}$ produced a profound break with the prevalent English understanding of law and punishment with which he was surrounded.

\footnotetext{
${ }^{21}$ Foucault is clearly correct in saying that change occurred, though he overemphasises the role of new institutions by regarding them as 'the most visible aspect of various, more profound processes'. See Foucault, Discipline and Punish, p. 210.

${ }^{22}$ Claude Adrien Helvétius, De l'esprit, Paris, 1758. Jean-Jacque Rousseau, Discours sur l'origine et les fondements de l'inégalité parmi les homes, Amsterdam, 1755, and Du Contrat Social, Amsterdam, 1762.

${ }^{23}$ See 'Introduction', in C. Beccaria, On Crimes and Punishments: Translated from the Italian in the Author's Original Order, trans. D. Young, Indianapolis, 1986.

${ }^{24}$ On the positive reception given to Beccaria see 'Cesare Beccaria: The Influence of Dei Delitti e delle Pene', Radzinowicz, English Criminal Law, p. 277-80.

${ }^{25}$ Douglas Hay suggests that 'the rhetoric of Whiggism denied that arbitrary measures existed and claimed that the criminal law was already fixed and determinate'. See 'Property, Authority and the Criminal Law', Albion's Fatal Tree, Crime and Society in Eighteenth-Century England, ed. D. Hay, P. Linebaugh, C. Winslow, J. Rule, E.P. Thompson, London, 1975, p. 58.

${ }^{26}$ On Bentham's critique of the common law (or, more specifically, judge-made law) see Postema, Bentham and the Common Law Tradition, D. Lieberman, The Province of Legislation Determined, Cambridge, 1989, and P. Schofield, 'Professing Liberal Opinions: The Common Law, Adjudication and Security in Recent Bentham Scholarship', Legal History, xvi. (1995), pp. 350-367.
} 
Yet, despite the direction taken by Bentham he also continued to hold much in common with his English contemporaries. During the later 1770s and 1780s Bentham's ideas were in accord with the general consensus in England regarding the purpose and forms of punishment as identified in the works of men such as William Blackstone and William Eden. ${ }^{27}$ The immediate end of punishment was, they all agreed, to deter future crime; and, on a wider scale, they concurred that punishment ought prominently to protect the liberties of law-abiding citizens. ${ }^{28}$ In practical terms this agreement amongst many writers of the early to mid-1770s displayed itself in their showing a collective distaste for imprisonment as a punishment. This distaste was shared by Bentham. By 1778, however, Bentham, along with others such as Eden for example, had come to place great value on the possibilities offered by imprisonment as a means of achieving their theoretical ends of reformation, disablement and example. ${ }^{29}$ Clearly great changes were underway at this period, and Bentham was very much at the forefront of them. It has been well established that the penitentiary idea of imprisonment had its roots both in the utilitarian thought exemplified by Bentham, and in the concepts of natural justice and natural religion permeating the thought of less radically minded men such as Eden. ${ }^{30}$ Bentham's interest in imprisonment was undoubtedly stimulated by contemporary debate and government policy

\section{Section 3: The Main Components of Bentham's Theory of Punishment}

Bentham's utilitarian perspective on punishment, so greatly influenced by Beccaria, identified the sources of motivation as the key to understanding what was involved in the encouragement of law-abiding behaviour. ${ }^{31}$ Consequently, his discussion of motivation provides the obvious starting point for any analysis of his discussion of punishment.

\footnotetext{
${ }^{27}$ See William Blackstone, judge and first Vinerian Professor of Law at Oxford, Commentaries on the Laws of England, 4 vols., Oxford, 1765-9; and William Eden, first Baron Auckland, statesman and diplomatist, Principles of Penal Law, London, 1771.

${ }^{28}$ This is not to deny, however, that they profoundly disagreed about the meaning of the word 'liberty'.

${ }^{29}$ On these ends in Bentham see IPML, p. 158, note a.

${ }^{30}$ See Ignatieff, A Just Measure of Pain, ch. 3; and Semple, Bentham's Prison, ch. 2.

${ }^{31}$ On the sanctions as forms of social motivation see D. Baumgardt, Bentham and the Ethics of Today, Princeton, 1952, pp. 218-21.
} 


\subsection{The Sources of Motivation Equated to the Sources of Punishment}

In Chapter 3 of IPML Bentham introduced a specific and fundamental division of the sources from which pain described as 'punishment' could be said to originate. Drawing on his wider philosophy, he placed great emphasis on the variety of directing sanctions, and he carefully detailed the effective restraints on behaviour derived from the four sources of pain and pleasure. These he termed as the physical, political, moral and religious sanctions. ${ }^{32}$ Thus pain, he explained, came from nature as the physicial sanction, from the operation of a magistrate operating according to a sovereign's will as the political or legal sanction, from the spontaneous disapproval of an individual's community as the moral sanction, and finally, from the 'hand of a superior invisible being' as the religious sanction.

In his attempt to elicit a more 'scientific' approach to the debate on punishment Bentham differed considerably from his contemporaries, not only with his expression of legal punishment as the embodiment of an unquestionable evil, ${ }^{33}$ but also with this broader use of the term 'punishment' itself. Punishment was, for Bentham, a particular category of pain, produced not just as the result of some individual action, but of an action that could be labelled an 'offence'. ${ }^{34}$ In Bentham's words, 'the idea of punishment presupposes the idea of offence: punishment, as such, not being inflicted but in consideration of offence'. ${ }^{35}$

The development of Bentham's understanding of the motivating sanctions, as responses to such offending, has been widely documented. From as early as $A$ Fragment on Government and A Comment on the Commentaries, three sanctions, the political, ${ }^{36}$ moral and religious, are discussed. Later, in IPML, a fourth sanction (the

\footnotetext{
${ }^{32} I P M L$, p. 35 .

${ }^{33}$ See the famous quote on punishment as an evil at, IPML (CW), p. 158; for Richard Smith's version see, Rationale, p. 1. Bentham followed Hobbes in describing punishment as an evil. See Leviathan, p. 202: 'A punishment, is an evil inflicted by public authority, on him that hath done, or omitted that which is judged by the same authority to be a transgression of the law; to the end that the will of men may thereby the better be disposed to obedience'. This view of punishment stood in contrast to the general view, particularly of practising magistrates, that since punishment satisfied the love of symmetry and the desire for vengeance it could be regarded as a good: see Halévy, Philosophic Radicalism, p. 55.

${ }^{34}$ The actual pain felt was the same as any other pain: pain was pain for Bentham regardless of its source. See IPML (CW) p. 36, where he suggested pains 'differ not [...] in kind'.

${ }^{35}$ Ibid., p. 4.

${ }^{36}$ The political sanction incorporates the legal sanction; the moral sanction is synonymous with the popular sanction. See Deontology (CW), ed. A. Goldworth, Oxford, 1983, pp. 151-152 n.
} 
physical) was identified $;{ }^{37}$ and finally, in the unfinished Deontology of 1814 , the role of 'sympathy' was given a new classification as a fifth independent sanction. ${ }^{38}$

This aspect of his thought introduced a subtle and sophisticated element to the debate that proved to be of profound importance for both Bentham and later penal discussion. In one very practical sense, this variety of motivational factors explains Bentham's desire to reduce the involvement of litigants, prosecutors, magistrates and judges in the maintenance of lawful behaviour, since it would be unreasonable to expect the range of individual motivation to be satisfactorily influenced solely by legal means. ${ }^{39}$ In other words punishment produced more pain for an offender than the purely legal kind. This held great importance for his basic theory and can perhaps be best understood by next considering his notion of the distribution of pain resulting from the imposition of a legal sanction - the 'artificial' pain inflicted by a state's system of law. ${ }^{40}$

\subsection{The Distribution of Pain}

The analysis of the distribution of pain, as presented in IPML, illustrates how pain from the political, or legal, sanction informs Bentham's entire penal theory and forms a central component of his philosophy of punishment. This original appreciation of the diffusion of the pain of punishment provided further foundations both for Bentham's attack on common, or judge-made, law and for his suggestions for reform. He believed contemporary theories entirely misunderstood the action of pain produced by legal punishment and concluded that only a utilitarian system of positive law could respond to the complexities of offending behaviour.

Again, seeking a 'scientific' approach to punishment, Bentham went to considerable lengths to discover the effect of pain as it was inflicted on society, both

\footnotetext{
${ }^{37}$ IPML (CW) p. 34.

${ }^{38}$ See Deontology $(C W)$, pp. xxi, 183, 152, 197, and 201-4. Bentham made this further distinction when he came to regard the social or sympathetic feelings aroused by the consideration of pleasure or pain experienced, or about to be experienced, by another person as having a fundamentally distinct origin compared with pleasures and pains of a self-regarding kind. He concluded that the source of such feelings ought to be classified separately. For a discussion of the concept of sympathy in the eighteenth century see, F.L. Van Holthoon, 'Adam Smith and David Hume: with Sympathy', Utilitas, v. (1993), pp. 35-48.

${ }^{39}$ Whilst Bentham sought a reduction in the influence of judges he ultimately concluded that their discretionary assessment was an essential requirement for a utilitarian, legal system. See Postema, Bentham and the Common Law Tradition, p. 349.

${ }^{40}$ Pain was 'artificial' because it was deliberately and specifically man-made, or 'annexed by political authority to an offensive act, in one instance': see IPML, p. 157. All other pains of punishment were deemed to be natural.
} 
by offences and punishments. From the perspective of pain caused by offending, he suggested a single test sufficient to determine whether an act was 'wrong', and whether it ought consequently to be classified as an 'offence' and made preventable by law. This test sought it identify the experience of pain suffered by some assignable or unassignable individual or individuals. ${ }^{41}$ The presentation of, and emphasis on, criminal behaviour as depending upon harm experienced by an individual and forming an assault upon the wider community can be found in Beccaria's Crimes and Punishments, but Bentham's use was substantially different from Beccaria's.

Of crucial importance was Bentham's insistence that any assessment of the extent of harm inflicted was dependent upon the motive, circumstances and intention under the influence of which an act was carried out. Beccaria, on the other hand, seems to have been daunted by the variety and complexity of circumstances that his argument suggested might need to be accounted for, and, in an attempt to simplify such assessment, he rejected the possibility of ever being able to gauge the 'intention' of an offender. Bentham clearly believed such an assessment was possible, and consequently considerations of intention, motive and disposition of an offender formed a central feature of his own utilitarian assessment of harm done by an offence and danger threatened by the offender in future.

Bentham believed the mischief of any act could be divided into two parts. The first he called 'primary' mischief, which related to the pain sustained by an assignable individual or individuals. The second part he labelled 'secondary' mischief, for, whilst clearly originating from the former, this secondary mischief extended throughout the whole, wider society, affecting innumerable unknown, unassignable, individuals. Most eighteenth-century discussions of punishment, from Montesquieu to Kant, had similarly adopted a definition of mischief as a painful or detrimental act against known persons, but this often formed the end as well as the beginning of the analysis of the 'effects' of an offence.

So with retributive justice, for example, it was possible for retaliation to be applied on behalf of the victim in proportion to the pain suffered by that specific person. Pain was not seen to radiate beyond the immediate sufferer from the offence; or, if it was recognised, it was not taken into account in consideration of the

\footnotetext{
${ }^{41}$ 'Is an offence committed? it is the tendency which it has to destroy, in such or such persons, some of these pleasures, or to produce some of these pains, that constitutes the mischief of it, and the ground for punishing it': IPML (CW), p. 49.
} 
seriousness of the offence. With Bentham, however, even with this most easily identifiable part of the mischief of an offence, he carefully distinguished between two distinct branches: the 'original' - being the immediate suffering of a person on their own account; and the 'derivative' - being the share of suffering which might fall on some other assignable person or persons. Bentham was clearly including suffering conventionally excluded from assessments of punishment since he incorporated within this category those individuals who suffered by way of direct connection with the victim, or simply from a sympathetic feeling towards the victim. ${ }^{42}$

This broad understanding of 'pain' as a varied product of offences enabled Bentham to draw distinctions regarding the manner in which offences affected the society in which they were perpetrated. The benefit of approaching the question from such an angle was to open up numerous categories of pain-producing mischiefs, and therefore to better focus and effect to any corrective application of penal suffering.

In this sense an understanding that an offence was operating in a certain manner on those witnessing, or learning of such an offence, might perhaps have been more important than the question of precisely quantifying how much mischief was being produced. It could be said, therefore, that Bentham's analysis was more concerned with recognising the action of pain, unhappiness, or fear, and defining their operation in specific directions, than it was in calculating the precise quantities of pain being created. ${ }^{43}$ With Bentham's concern for the condition of unknown, 'unassignable' individuals, who were affected at a second, third or even greater remove from the instigating mischief, there remained, it seems, little possibility of precise calculation. ${ }^{44}$ Thus, and perhaps paradoxically, we are presented with a theory which seeks to 'calculate' likely consequences in detail yet without insisting on the assigning of precise quantities in order to be effective. The question must then be, did Bentham sacrifice precise quantification for a better appreciation of pain's complex distribution? With many references to quantification this seems improbable, yet Bentham's theory

\footnotetext{
${ }^{42}$ Ibid., p. 144.

${ }^{43}$ Although Bentham appreciated the difficulty in calculating the 'sums' of pain at work, the numerous directions in which he was able to define mischief as capable of working does seem to go some way towards what Beccaria called a 'mathematically rigorous investigation'. See Beccaria, Crimes and Punishments, p. 17. Bentham's interest in the variety of directions in which pain can operate appears to relate to the notion of 'multi-dimensional utility' as discussed in T. Warke, 'Multi-Dimensional Utility and the Index Number Problem: Jeremy Bentham, J.S. Mill, and Qualitative Hedonism', Utilitas, xii. (2000), pp. 176-203.
} 
is certainly at its most sophisticated and demanding as it attempts to account for the intricate and widespread nature of the distribution of pain originating from apparently 'simple' offensive actions, aware, as it is, that all can never be known for sure.

\subsection{Proportionality in Punishment}

Closely related to Bentham's notion of the distribution of pain of punishment are his thirteen rules of proportion. The development of specific rules for the purpose of better proportioning punishments to offences was clearly an obvious contribution to the Enlightenment project of rational explanation, and better regulation, of existing practice. These rules embodied a method of proportioning formed from an overwhelmingly utilitarian perspective. ${ }^{45}$ With nine of his rules he established the foundations for increases in amounts of pain provided as punishment. ${ }^{46}$ Three others protected against excesses: rules five and six limited increases in pain, whilst rule twelve provided for a positive diminution. Finally, a thirteenth rule stressed the point that precise calculation was not required and small disproportions might be ignored. With this plan Bentham sought a mechanism for both an accurate assessment of offending and the controlled imposition of punishment.

The crux of the theory was an overwhelming emphasis placed on quantities of pain and in this respect the first five rules were of most importance:

the four first [rules], we may perceive, serve to mark out the limits on the side of diminution: the limits below which a punishment ought not to be diminished: the fifth, the limits on the side of increase: the limits above which it ought not to be increased. ${ }^{47}$

Not only was this fifth rule of proportion, which limited the increase, central to Bentham's scheme for the reduction of punishments as observed in contemporary legal practice, but each of the first four rules added quantities of pain in such a way as to constantly make any increase proportional to the perceived increase in the severity

\footnotetext{
${ }^{44}$ Baumgardt has stressed, following Dumont, that whilst an 'arithmetic' approach is frequently called upon, its precision is problematic, and no less so for his theory of punishment than for his moral calculus in general. See Ethics of Today, pp. 361, and 459.

${ }^{45}$ Some small allowance was made for non-utilitarian considerations, such as satisfaction provided for victims of offences, but this was completely subordinated to Bentham's utilitarian consequentialism.

${ }^{46}$ See IPML (CW), Ch. 14, rules 1-4 and rules 7-11, pp. 166-171.

${ }^{47}$ Ibid., p. 169.
} 
of the offence. Seeking such control in the infliction of pain reveals Bentham to be on common ground with a prominent strain of contemporary English reform. ${ }^{48}$ Yet, more lenient punishment could only ever be expressed by Bentham as a reduction in the quantity of pain linked proportionately to a new, lower assessment of the pain spread by the offence. In other words, less pain of punishment could only be justified once his theory of the distribution of pains had discovered the degree of mischief to be, in fact, lower than that conventionally assumed. In these terms it can be seen that Bentham's abovementioned theory of the distribution of pains was as important to his demand for a reduction in levels of severity as was his novel theory of proportion.

\subsection{Calculation and the Surfeit of Pleasure over Pain}

A further complication was introduced with Bentham's suggestion that to be appropriate the evil of punishment ought ultimately to produce a surfeit of pleasure over pain. ${ }^{49}$ Such a requirement carried with it the implication that each and every legal punishment, regardless of the category to which it might belong, had the potential of becoming, on each new occasion it was used, morally unacceptable. ${ }^{50}$ That is to say, in Bentham's terms, any offence might be found 'unmeet for punishment ${ }^{51}$ One result of an emphasis on future benefit could be to encourage the judge, at the point of sentencing, to take the broadest view of the future consequences of both offence and recommended punishment. The focus of any 'calculation' was again identified in extremely general terms. This would, as with his theory of distribution, seem to shift Bentham's position even further away from the advocation of the need, or possibility, of precise calculation, since, with a more general approach, unassignable pains were once again included in the assessment and precise effects of offending actions could never be known for sure.

The consequences of such general, consequentialist thinking offered a significant threat to conventional, eighteenth-century theories, both of retribution and

\footnotetext{
${ }^{48}$ Found represented in both Blackstone's and Eden's use of Beccaria's work.. For a more detailed discussion see A.J. Draper, 'Cesare Beccaria's Influence on English Discussions of Punishment', History of European Ideas, xxvi. (2000), pp. 177-99.

${ }^{49}$ The idea of a future surfeit of pleasure is derived from notions of punishment needing to be 'profitable' given at $I P M L$, p. 163.

${ }^{50}$ This appears to be consonant with the "classic liberal doctrine that non-restriction of liberty needs no defence but intrusion on it always requires justification'. See Introduction to 'Jeremy Bentham and J.S. Mill', Modern Political Theory from Hobbes to Marx, ed. J. Lively and A. Reeve, London, 1989, p. 191.

${ }^{51}$ IPML, chapter 13.
} 
deterrence. Notions of retributive threats were almost wholly removed from Bentham's theory of punishment, but so too was any justification of a disproportionate deterrent threat. ${ }^{52}$ In fact, if it could be known for sure that a similar offence would never again be committed, then, from his utilitarian standpoint, he would find no justification for the infliction of any punishment. For Bentham pain, and thus punishment, was always a social negative, unless it promised greater pleasure in future.

\section{Section 3.5: Bentham's Favoured Forms of Punishment}

Bentham's preferred forms of punishment certainly changed over the course of his life. In his earlier writings a variety of corporal punishments were recommended, ${ }^{53}$ in his middle years the panopticon penitentiary was his prime interest; and finally, in the 1820 s, evidence is available to suggest he felt an increasing attachment to nonafflictive, though still complex, punishments, especially those of banishment and fining. ${ }^{54}$

For Bentham a satisfactory mode of punishment had to satisfy some $\mathrm{e}^{55}$ of his eleven defined 'properties' of punishment. ${ }^{56}$ Most importantly, punishment had to provide a variable quantity of pain in response to the varying quantities of mischief caused by offences. ${ }^{57}$ This continuing stress on quantification always remained a constant rule governing Bentham's assessment of an appropriate type of punishment.

\footnotetext{
${ }^{52}$ A retributive threat is one which threatens the infliction of 'good' punishment, as a desert, for a past offence. Retributive punishment also includes the modern, derived concept of 'weak retributivism [...] which regards desert of unpleasant treatment as a necessary but not a sufficient condition for punishment'. See N. Lacey, State Punishment: Political Principles and Community Values, London, 1988, p. 53.

${ }^{53}$ Some were conventional, others were not: see Radzinowicz, English Criminal Law, pp. 384 n, and $388 \mathrm{n}$. Bentham's ideas for devices and contrivances included elaborate torments such as the thinbacked, iron-horse for the punishment of highwaymen, and the iron frame for the half-roasting of those guilty of fire-raising. And various suggestions for elaborate displays, supposed to ridicule offenders, succeed only in descending into black comedy. For example, he suggests piercing the hand of forgers with a pin - but arranged in imitation of a pen; and of setting the deserter of children on a pedestal, garlanded with life-size figures of his offspring, and with an inscription comparing him to an ostrich which 'droppeth her egg in the sand and careth not what becometh of her young'. UC cxliii. 28. All of these outlandish suggestions come from his earliest manuscripts. For a lively discussion see Semple, Bentham's Prison, pp. 36-8.

${ }^{54}$ Complex punishments are those which attempt to achieve several ends by several means. For Bentham's catalogue and discussion of such punishments see Bowring, i. 490-516.

${ }_{55}$ An effective form of punishment had to embody as many properties of punishment as were required to satisfy Bentham's rules of proportion.

${ }^{56}$ See IPML, ch. 15.

${ }^{57} \operatorname{IPML}(\mathrm{CW})$, p. 175.
} 
Closely related to this key element of variability were the second and third properties of equability and commensurability. ${ }^{58}$ The former identified an equalisation of pain necessary when the same punishment was applied to different individuals, so ensuring that offenders received the same pain if they committed the same offence. But it was the latter property of commensurability on which great importance was placed, for this allowed punishments to be proportioned to other punishments.

These elements combined to encourage Bentham to abandon in the late 1770s his support for simply corporal inflictions of pain, and to join the enthusiastic contemporary pursuit of an increased use of penal incarceration. In terms of theory, the obvious advantage that imprisonment, and particularly panopticon imprisonment, offered was the greatly improved provision for the property of 'exemplarity'. ${ }^{59}$ Deterrence was a primary aim, and if prisoners could be seen to be suffering, then the purpose of the punishment could be better fulfilled:

Example, or the preventing others by the terror of the example from the commission of similar offences. This is the main end of all punishment, and consequently of the particular mode [panopticon] here in question. ${ }^{60}$

By the early-1790s, therefore, panopticon imprisonment had become without question the dominant mode of punishment promoted by Bentham. It offered adequate punishment for most, if not all, serious offences, for it could inflict both simple and complex punishment as occasion demanded. Additionally, it used the means of reward to increase its properties of reformation. Obviously Bentham envisaged the panopticon as an institution operating primarily on the psychological motivations of those incarcerated, though it should be noted that 'corporal' pain still formed an intrinsic part of the punishment. This was not, therefore, simply punishment of 'the mind' as it has sometimes been portrayed, ${ }^{61}$ but equally it was an effective punishment of the body, and it could be so in a variety of ways.

Throughout the period of Bentham's intense focus on penitentiary imprisonment the main legal punishment for serious offences continued to be capital punishment.

\footnotetext{
${ }_{59}^{58}$ Ibid., pp.175-6.

${ }^{59}$ Ibid., p. 178.

60 'Panopticon; Postscript - Part II. Principles and Plan of Management', Bowring, iv. p. 122 (originally published in 1791).

${ }^{61}$ See Foucault, Discipline and Punish, passim.
} 
The death penalty was universally attacked by penal reformers in the late eighteenth century, though it was not until 1830 that Bentham published the reasons for his own opposition to capital punishment. He drew up a pamphlet on the death penalty, specifically for the people of France ${ }^{62}$ and throughout this text he displays all the fundamental penal principles he had first established in 1776-8. In concise terms, Bentham denounced capital punishment for possessing the detrimental qualities of inefficiency, irremissibility, positive maleficence (i.e. tending to produce crimes), and for the enhancement of evils produced by ill-applied pardons. ${ }^{63}$ These were described as features of inaptitude, by which the punishment undermined the purpose for which it was intended, this being ultimately to produce future pleasure by inflicting legal pain. In Bentham's view the pains resulting from capital punishment, and more particularly from the widespread threat of capital punishment, were judged to be considerable and excessive.

\section{Conclusion}

Several points can be made, therefore, when examining the development of Bentham's theory of punishment and considering his preferences for forms or modes of punishment. Once the construction of his penal theory is seen to be independent of any particular mode of punishment, and especially once it is disconnected from the constant association with panopticon imprisonment, his theoretical analysis displays considerable consistency. The ends of punishment always remain the same: reformation, disablement and example, ${ }^{64}$ and constant, overwhelming emphasis is placed on the assessment of quantities of pain inflicted in pursuit of these ends.

At the root of all his practical suggestions for punishment lies his treatment of an individual's motivation to act. Understanding what motivates the individual to offend is presented as the key to understanding how to prevent such offending. And general prevention, for Bentham, depends predominantly on some form of deterrent example. Those who offended seriously against society ought to be punished, first for the benefit of the society against which they have shown a disposition to offend, and second, for their own benefit, which is said to come from the opportunity for reform.

\footnotetext{
${ }^{62}$ Published as Jer. Bentham to his fellow citizens of France on death punishment, London, 1831. The same text was included in Bowring as an Appendix, 'On Death Punishment'. See Bowring, i. pp. 52532. It has been suggested that the pamphlet was published because of the general interest in capital punishment following the events in Paris of 1830: see Crimmins, 'Strictures on Paley's Net', p. 33. ${ }^{63}$ See 'On Death Punishment', Bowring, i. p. 526-31.
} 
This 'reform' can be achieved both by punishment and reward. If incarcerated, for example, individuals will be habituated to new routines and activities designed to prepare them for 'survival' in an industrial environment. They will be rewarded when their behaviour is deemed non-offensive by the governing authorities. Throughout his later discussions of imprisonment Bentham offers a means for restraining, perhaps even changing, the motivational perspectives of offenders, such that their behaviour may be brought into accord with societal and legal norms. For this he has been soundly criticised, and clearly many of his practical suggestions are entirely inappropriate for the contemporary penal environment. His underlying theory, however, may not be so easily discarded, and much of what he says, especially in terms of 'disposition' and 'intention' of offenders, and distribution of pain in society, deserves further consideration.

\section{(c) (1) $\odot \Theta$ \\ BY NC ND}

This work is licensed under the Creative Commons Attribution-NonCommercial-NoDerivs 2.0 UK: England \& Wales License. Under the terms of this licence, you are allowed to copy and distribute this work, but must give the original author credit. You not use this work for commercial purposes, nor alter or transform this work, without prior permission from the author. To view a full copy of this licence, visit: http://creativecommons.org/licenses/by-nc$\mathrm{nd} / 2.0 / \mathrm{uk} /$ or send a letter to Creative Commons, 444 Castro Street, Suite 900, Mountain View.

${ }^{64} I P M L$, p. 158. 